\title{
PRZEDMOWA DO WYDANIA POLSKIEGO
}

Należy wyrazić podziękowanie kolegom, którzy podjęli się dużego trudu przethumaczenia na język polski tego podręcznika. Jest on napisany przez autora, który ma olbrzymie doświadczenie, reprezentuje dobrą szkołę kliniczną, a nade wszystko ma talent dydaktyczny. Jest to nie tak często spotykane uzdolnienie, które występuje tu $\mathrm{w}$ tak swoistym ujęciu poszczególnych zagadnień.

Skorzystać z tego podręcznika mogą nawet doświadczeni koledzy, którzy mają już wyrobiony pogląd na poszczególne sytuacje położnicze, na pewno przyswoją sobie oni szereg oryginalnych ujęć autora. Młodzi koledzy latwiej uporządkują sobie jeszcze nie utrwalone informacje. Wytyczne zawarte w tym podręczniku będą dia każdego niejako szkieietem, na który będzie on sam nakładać dalsze swoje spostrzeżenia.

Student otrzymuje od razu wiele wytycznych i powtarzających się uwag uwypuklających, co jest ważne, a co mniej istotne; położono akcent na niebezpieczne momenty, których nie wolno przeoczyć pod groźbą wystąpienia powikłań.

Podręcznik mial szereg wydań, wytrzymal próbę życia, zostal unowocześniony. Cieszymy się, że idee autora zostały zachowane przez utrzymanie w polskim wydaniu nawet charakterystycznych graficznych akcentów sprawiających, że książka ta zajmuje miejsce pomiędzy zwykłym podręcznikiem a wykładem.

Prof. dr med. IRENEUSZ ROSZKOWKI 